\title{
Performance of Pigeon Pea (Cajanus cajan) Varieties under Different Soil Amendments in Ndokwa, Delta State, Nigeria
}

\author{
C.O. Ossai, S.A. Ojobor, S.C. Akpeji, F.N. Emuh
}

10.18805/ag.DF-384

\begin{abstract}
Background: Pigeon pea is an important legume worldwide that is not cultivated by the farmers in Ndokwa, Delta State. Hence, the study looked at the possibility of evaluating the potential of pigeon pea in Ogume, a community in Ndokwa.

Methods: Top soils were collected from a fallowed land mixed thoroughly and filled into $4 \mathrm{~kg}$ bags and were divided into 3 . The $1^{\text {st }}$ was amended with poultry manure, $2^{\text {nd }}$ was NPK 15:15:15 amended and $3^{\text {rd }}$ was without amendment, tested with two varieties of Cajanus cajan. The experiment was a 2 by 3 factorial, in a completely randomized design with 3 replicates. Residual effects of the amendments were evaluated in 2020. Soil samples were taken to establish the fertility status before amendment and at harvest. Data were taken on the agronomic and yield parameters and were analyzed using ANOVA while means were separated using LSD at $\mathrm{P} \leq 0.05$.

Result: Result obtained showed that the tallest plants $(9.83 \pm 0.51)$ were observed in the poultry manure in 2019 while the fallowed plots had the tallest plants $(11.17 \pm 0.49)$ in 2020 , while in both years, the number of pods and dry pod weight was insignificant among the treatments and varieties. This shows that farmers do not need to spend much finance in amending the soil for pigeon pea cultivation in Ndokwa community, Delta State.
\end{abstract}

Key words: Fallow system, Genotypes, Pigeon pea, Poultry manure, Soil amendments, Soil fertility.

\section{INTRODUCTION}

Pigeon pea (Cajanus cajan) is a multipurpose legume in the family of Fabaceae. It is the sixth most important legume crop in the World (FAO, 2015) because of its source as food, fuel wood, straw, fodder and also enriches the soil fertility (Tabo et al., 1995). Despite these important characteristics, the yields are still very low in Southern Nigeria (Emefiene et al., 2014). Ndokwa is located in the southern guinea savanna agroecological zone and the major occupation of the inhabitants is farming. Maize, cassava, yam and plantain are the predominantly cultivated crops in a fallowed system. Sticking to these crops is partly due to the belief that they are the suitable crops for their type of soil and climatic condition. They have not nurtured the idea of cultivating other food crops such as pigeon pea which inevitably will increase their returns. The above mention crops are mostly cultivated as a sole crop or in mixed farming system like maize and cassava, maize and yam or having maize, yam and cassava in same field with varied planting intervals (Ureigho et al., 2020).

The pigeon pea is an important pulse consumed by millions of people around the world due to its high nutritional contents (Ojwang et al., 2016). The plant has the advantage of thriving well in a semi-arid region where moisture availability is inadequate (Okoko et al., 2002). This make the crop an alternative to other legumes like cowpea that are drought intolerant, hence it can play a vital role in not only providing food from the pods but also soil nutrient enrichment for the utilization of other surrounding crop in a mixed cropping system. In a region like Ndokwa were fertilizers of any kind are hardly used due to cost and availability, fallow system has been the sole means of replenishing lost nutrient.
Department of Agronomy, Delta State University, Asaba, Delta State, Nigeria.

Corresponding Author: C.O. Ossai, Department of Agronomy, Delta State University, Asaba, Delta State, Nigeria.

Email: c.ossai@cgiar.org

How to cite this article: Ossai, C.O., Ojobor, S.A., Akpeji, S.C. and Emuh, F.N. (2021). Performance of Pigeon Pea (Cajanus cajan) Varieties under Different Soil Amendments in Ndokwa, Delta State, Nigeria. Agricultural Science Digest. DOI: 10.18805/ag.DF-384.

Submitted: 21-07-2021 Accepted: 03-12-2021 Online: 25-12-2021

Another practice of reclaiming soil nutrient involves the cultivation of cereals and legumes or deep feeding crops with legumes, owing to their feeding habits (Kumawat et al., 2013) and pigeon pea has been reportedly utilized in this regard to boost the productivity of different crops (Jat and Ahlawat, 2010; Balpande et al., 2016). However, focus has been given to other crops in terms of fertilization, with much neglect to pigeon pea which is believed to add to the means of soil fertilizing. This has drastically reduced the yield obtained from pigeon pea in such context, necessitating the cultivation of pigeon pea in a monoculture system with view of properly boosting the productivity with both organic and inorganic fertilizers (Mallesha et al., 2014). As such, this study evaluates two early maturing varieties of Pigeon pea amended with NPK 15:15:15, poultry manure and fallowed plot in Ogume, a community in Ndokwa, Delta State, Nigeria to assess which fertilization method that is best suited for pigeon pea production or if fertilization is inconsequential in the region. 
Performance of Pigeon Pea (Cajanus cajan) Varieties under Different Soil Amendments in Ndokwa, Delta State, Nigeria

\section{MATERIALS AND METHODS \\ Experimental site}

The experiment was carried out Ogbagu Ogume community of Ndokwa West Local Government Area of Delta State situated at Latitude $5.7652^{\circ} \mathrm{N}$ and Longitude $6.3341^{\circ} \mathrm{E}$. The soil type in the farm area is loamy and the inhabitant practices fallow system as means of farm nutrient enrichment.

\section{Soil analysis}

In 2019, Topsoil were collected from the fallowed land and properly mixed up to form a composite sample. Pre soil analysis was carried out at the analytical laboratory of the International Institute of Tropical Agriculture (IITA), Ibadan. In 2020, soil samples were collected from each amendments serving as treatments and were analysed as post soil analysis.

\section{Crop husbandry}

Topsoil were collected and filled into $4 \mathrm{~kg}$ experimental bags. The bags were divided into 3 , one part was used without an amendment whereas the other two parts were amended with poultry manure and NPK 15:15:15 at the rate of $10 \mathrm{t} / \mathrm{ha}$ and $250 \mathrm{~kg} / \mathrm{ha}$, respectively. Two genotypes (ICP7992 and ICP7343) of Cajanus cajan were sourced from IITA and were sown singly in each bag.

\section{Experimental design}

The experiment was a 2 (genotypes) by 3 (treatments) factorial in a completely randomized design with 3 replicates.

\section{Data collection and statistical analysis}

Morphological data were taken on plant height, number of leaves and leaf area at 3, 6 and 9 weeks after planting whereas yield data were taken on the days to $50 \%$ flowering, number of pods per plant, dry pod weight, dry grain yield and days to maturity. Data collected were analyzed using ANOVA while genotypic and soil amendment means were separated using LSD at $\mathrm{P} \leq 0.05$. In 2020 , the residual effects of the soil amendment were evaluated by planting in the same bags and arrangements.

\section{RESULTS AND DISCUSSION \\ Effect of soil amendments on the growth parameters of two Cajanus cajan varieties}

Steady growth occurred with age and height of the two varieties differed significantly across the two planting seasons (Table 1) whereas, effects of soil amendment only differed significantly at nine weeks old. Plants in bags containing NPK 15:15:15 were significantly taller (11.17 \pm 0.51$)$ compared to those in fallow bags $(7.50 \pm 0.51)$ and poultry manure $(9.83 \pm 0.51)$. In 2020 however, the tallest plants were found in fallowed bags $(11.17 \pm 0.49)$, but not significantly different from the NPK 15:15:15 (10.50 \pm 0.49$)$. The number of leaves produced by the genotypes was only significant in 2019, with ICP7992 having 9.78 \pm 0.18 which was significantly higher than ICP7343 $(9.00 \pm 0.18)$ at 9 weeks old (Table 2). Fallowed bags had the highest $(9.83 \pm 0.22)$ however, it was not significantly different from the poultry manure but significantly higher than NPK 15:15:15 treated bags. Leaf areas of the two genotypes across the planting seasons were not significant (Table 3 ).

The findings of this study show a steady growth of the genotypes evaluated in the three soil conditions in both planting seasons. However, the NPK 15:15:15 and poultry manure amended soil supported the growth of the plants more in the first season, while the fallowing performed better in the following season. This shows that the nutrient in the fertilizer used for the amendment have been depleted by the crops in the first season as the residual performed less than the fallowed soil in the following planting season. Tian et al. (2001) attributed vegetative fallow approach as a biological way of reclaiming lands productivity. Also the higher agronomic performance of the ICP7343 genotype in the following season suggests that the genotype is more stable and adapts better to a low nutrient soil. Folu et al. (2007) had earlier suggested that the variations in the genotypic performance of pigeon pea is due to their differential adaptation to varied climatic and soil conditions.

Table 1: Effect of soil amendments on the plant height of two genotypes of pigeon pea in both seasons.

\begin{tabular}{|c|c|c|c|c|c|c|}
\hline \multirow{2}{*}{ Treatments/genotypes } & \multicolumn{2}{|c|}{ Three weeks } & \multicolumn{2}{|c|}{ Six weeks } & \multicolumn{2}{|c|}{ Nine weeks } \\
\hline & 2019 & 2020 & 2019 & 2020 & 2019 & 2020 \\
\hline Fallow soil & $2.12 \mathrm{a}$ & $2.42 a$ & $5.33 a$ & $7.00 \mathrm{a}$ & $7.50 \mathrm{~b}$ & $11.17 \mathrm{a}$ \\
\hline NPK15:15:15 & $2.22 \mathrm{a}$ & $2.42 a$ & $6.50 \mathrm{a}$ & $6.33 a$ & $11.17 a$ & $10.50 \mathrm{ab}$ \\
\hline Poultry manure & $2.27 \mathrm{a}$ & $2.52 \mathrm{a}$ & $6.00 \mathrm{a}$ & $6.17 \mathrm{a}$ & $9.83 a$ & $9.33 b$ \\
\hline $\operatorname{LSD}_{(0.05)}$ & 0.34 & 0.5 & 1.42 & 0.84 & 1.57 & 1.51 \\
\hline SE & 0.11 & 0.16 & 0.46 & 0.27 & 0.51 & 0.49 \\
\hline ICP7992 & $2.31 \mathrm{a}$ & $2.84 a$ & $5.22 b$ & $7.00 \mathrm{a}$ & $9.44 a$ & $9.67 \mathrm{~b}$ \\
\hline ICP7343 & $2.09 a$ & $2.06 \mathrm{~b}$ & $6.67 a$ & $6.00 \mathrm{~b}$ & $9.56 \mathrm{a}$ & $11.00 \mathrm{a}$ \\
\hline $\operatorname{LSD}(0.05)$ & 0.28 & 0.41 & 1.16 & 0.68 & 1.28 & 1.23 \\
\hline SE & 0.09 & 0.13 & 0.38 & 0.22 & 0.42 & 0.4 \\
\hline
\end{tabular}

Means with the same alphabet down the groups are not significantly different at $5 \%$ level of significance, SE: Standard error, LSD: Least significance differences. 
Performance of Pigeon Pea (Cajanus cajan) Varieties under Different Soil Amendments in Ndokwa, Delta State, Nigeria

Table 2: Effect of soil amendments on the number of leaves of the two genotypes of pigeon pea in both seasons.

\begin{tabular}{lcccccc}
\hline \multirow{2}{*}{ Treatments / genotypes } & \multicolumn{2}{c}{ Three weeks } & \multicolumn{2}{c}{ Six weeks } & \multicolumn{2}{c}{ Nine weeks } \\
\cline { 2 - 7 } & 2019 & 2020 & 2019 & 2020 & 2019 & 2020 \\
\hline Fallow soil & $2.83 a$ & $3.00 \mathrm{a}$ & $5.83 \mathrm{~b}$ & $5.67 \mathrm{a}$ & $9.83 \mathrm{a}$ & $8.67 \mathrm{a}$ \\
NPK15:15:15 & $2.83 \mathrm{a}$ & $2.33 \mathrm{~b}$ & $6.00 \mathrm{~b}$ & $5.83 \mathrm{a}$ & $8.83 \mathrm{~b}$ & $8.83 \mathrm{a}$ \\
Poultry manure & $2.80 \mathrm{a}$ & $2.33 \mathrm{~b}$ & $6.67 \mathrm{a}$ & $5.50 \mathrm{a}$ & $9.50 \mathrm{a}$ & $9.17 \mathrm{a}$ \\
LSD $(0.05)$ & 0.51 & 0.59 & 0.66 & 1.11 & 0.66 & 1.68 \\
SE & 0.17 & 0.19 & 0.22 & 0.36 & 0.22 & 0.54 \\
ICP7992 & $3.00 \mathrm{a}$ & $2.56 \mathrm{a}$ & $6.67 \mathrm{a}$ & $5.89 \mathrm{a}$ & $9.78 \mathrm{a}$ & $8.78 \mathrm{a}$ \\
ICP7343 & $2.67 \mathrm{a}$ & $2.56 \mathrm{a}$ & $5.67 \mathrm{~b}$ & $5.44 \mathrm{a}$ & $9.00 \mathrm{~b}$ & $9.00 \mathrm{a}$ \\
LSD $(0.05)$ & 0.42 & 0.48 & 0.54 & 0.91 & 0.54 & 1.37 \\
SE & 0.14 & 0.16 & 0.18 & 0.29 & 0.18 & 0.44 \\
\hline
\end{tabular}

Means with the same alphabet down the groups are not significantly different at $5 \%$ level of significance. SE: Standard error, LSD: Least significance differences.

Table 3: Effect of amendments on leaf area of the two pigeon pea genotypes in both seasons.

\begin{tabular}{lcccccc}
\hline \multirow{2}{*}{ Treatments } & \multicolumn{2}{c}{ Three weeks } & \multicolumn{2}{c}{ Six weeks } & \multicolumn{2}{c}{ Nine weeks } \\
\cline { 2 - 6 } & 2019 & 2020 & 2019 & 2020 & 2019 & 2020 \\
\hline Fallow soil & $9.67 \mathrm{a}$ & $7.83 \mathrm{a}$ & $16.17 \mathrm{a}$ & $18.50 \mathrm{a}$ & $19.83 \mathrm{a}$ & $25.67 \mathrm{a}$ \\
NPK15:15:15 & $9.00 \mathrm{a}$ & $7.83 \mathrm{a}$ & $17.50 \mathrm{a}$ & $15.33 \mathrm{a}$ & $23.00 \mathrm{a}$ & $19.33 \mathrm{a}$ \\
Poultry manure & $10.17 \mathrm{a}$ & $8.00 \mathrm{a}$ & $21.67 \mathrm{a}$ & $16.83 \mathrm{a}$ & $28.17 \mathrm{a}$ & $23.50 \mathrm{a}$ \\
LSD $(0.05)$ & 3.3 & 2.14 & 7.49 & 4.96 & 9.02 & 6.66 \\
SE & 1.07 & 0.69 & 2.43 & 1.61 & 2.93 & 2.16 \\
ICP7992 & $11.22 \mathrm{a}$ & $8.00 \mathrm{a}$ & $20.78 \mathrm{a}$ & $16.56 \mathrm{a}$ & $25.00 \mathrm{a}$ & $21.56 \mathrm{a}$ \\
ICP7343 & $8.00 \mathrm{~b}$ & $7.78 \mathrm{a}$ & $16.11 \mathrm{a}$ & $17.22 \mathrm{a}$ & $22.33 \mathrm{a}$ & $24.11 \mathrm{a}$ \\
LSD $(0.05)$ & 2.7 & 1.75 & 6.11 & 4.05 & 7.37 & 5.43 \\
SE & 0.87 & 0.57 & 1.98 & 1.31 & 2.39 & 1.76 \\
\hline
\end{tabular}

Means with the same alphabet down the groups are not significantly different from each other at $5 \%$ level of significance, SE: Standard error, LSD: Least significance differences.

\section{Effect of soil amendments on yield parameters of two Cajanus cajan varieties}

In 2019 , the number of days to $50 \%$ flowering was significant while days to maturity were only significant in soil amendment effect (Table 4). The number of days taken by ICP7992 (103.00 \pm 2.03$)$ was significantly higher than ICP7343 (92.78 2 2.03). In the soil amendment effect, the plants grown in the fallowed soil took the longest number of days to produce flowers $(103.00 \pm 2.48)$, although, this was not significantly higher than the number of days taken by the plants grown in poultry manure bags $(101.83 \pm 2.48)$ but was significantly higher than the number of nodes taken by the plants grown in NPK 15:15:15 (88.83 \pm 2.48$)$. Number of days to maturity was highest in fallowed soil $(158.67 \pm 4.01)$ and significantly higher than those grown with NPK 15:15:15 (141.67 \pm 4.01$)$ in 2019. The number of days taken by plants grown in poultry manure $(160.67 \pm 4.86)$ was significantly higher than fallowed soil $(144.20 \pm 4.86)$. However, soil amendment types and genotypes were there were not significantly different in terms number of pods, the dry pod weight and the dry grain yield.

Despite the differential agronomic performance of the genotypes in the different soil status, the effect of soil amended types was negligible in the yield parameters of the two genotypes of pigeon pea (Table 5). This gives an advantage to the local farmers as less resources is will be channeled to amending the soil for the cultivation of pigeon pea in the area and this supports the findings of Folu et al. (2007), that pigeon pea can be used in soil reclamation, especially planting them as mixed crop with cassava and yam or sole planted a year before planting the deep feeders (Egbe and Adeyemo, 2006).

\section{Effect of different amendments on soil chemical properties at harvest}

The soil properties in Table 6 revealed varied significant contributions of the different amendment type on the soil relative to the initial soil status. The soil $\mathrm{pH}(6.20 \pm 0.09)$, organic carbon $(14.10 \pm 0.05)$, total nitrogen $(2.40 \pm 0.06)$, phosphorus (14.40 \pm 0.06$)$ and magnesium $(0.89 \pm 0.03)$ contents of the poultry manure amended treatment was significantly higher than the rest treatments including the pre soil status. Also, the calcium content $(1.84 \pm 0.03)$ of the poultry manure amended treatment was the highest, but it was not significantly higher than the NPK 15:15:15 amendment $(1.70 \pm 0.03)$, while both of them were significantly higher than the fallowed soil and the initial soil 
Performance of Pigeon Pea (Cajanus cajan) Varieties under Different Soil Amendments in Ndokwa, Delta State, Nigeria

Table 4: Effect of soil amendments and genotypes on number of days to flowering and maturity at both seasons.

\begin{tabular}{lcccc}
\hline \multirow{2}{*}{ Treatments / genotypes } & \multicolumn{2}{c}{ Days to 50\% flowering } & \multicolumn{2}{c}{ Days to maturity } \\
\cline { 2 - 5 } & 2019 & 2020 & 2019 & 2020 \\
\hline Fallow soil & $103.00 \mathrm{a}$ & $103.17 \mathrm{a}$ & $158.67 \mathrm{a}$ & $144.20 \mathrm{~b}$ \\
NPK15:15:15 & $88.83 \mathrm{~b}$ & $103.83 \mathrm{a}$ & $141.67 \mathrm{~b}$ & $152.33 \mathrm{ab}$ \\
Poultry Manure & $101.83 \mathrm{a}$ & $102.17 \mathrm{a}$ & $150.83 \mathrm{ab}$ & $160.67 \mathrm{a}$ \\
LSD(0.05) & 7.65 & 6.62 & 12.35 & 14.97 \\
SE & 2.48 & 2.15 & 4.01 & 4.86 \\
ICP7992 & $103.00 \mathrm{a}$ & $101.78 \mathrm{a}$ & $150.56 \mathrm{a}$ & $147.56 \mathrm{a}$ \\
ICP7343 & $92.78 \mathrm{~b}$ & $104.33 \mathrm{a}$ & $150.22 \mathrm{a}$ & $152.89 \mathrm{a}$ \\
LSD(0.05) & 6.25 & 5.41 & 10.04 & 12.22 \\
SE & 2.03 & 1.76 & 3.27 & 3.97 \\
\hline
\end{tabular}

Means with the same alphabet down the groups are not significantly different from each other at $5 \%$ level of significance, SE: Standard error, LSD: Least significance differences.

Table 5: Effect of soil amendments and genotypes on the number of pods, dry pod weight and dry grain yield in both seasons.

\begin{tabular}{lcccccc}
\hline \multirow{2}{*}{ Treatments / genotypes } & \multicolumn{2}{c}{ No of pods } & \multicolumn{2}{c}{ Dry pod weight } & \multicolumn{2}{c}{ Dry grain yield } \\
\cline { 2 - 6 } & 2019 & 2020 & 2019 & 2020 & 2019 & 2020 \\
\hline Fallow soil & $103.67 \mathrm{a}$ & $116.33 \mathrm{a}$ & $2.39 \mathrm{a}$ & $3.13 \mathrm{a}$ & $1.15 \mathrm{a}$ & $1.50 \mathrm{a}$ \\
NPK15:15:15 & $131.67 \mathrm{a}$ & $113.67 \mathrm{a}$ & $3.24 \mathrm{a}$ & $2.76 \mathrm{a}$ & $1.46 \mathrm{a}$ & $1.40 \mathrm{a}$ \\
Poultry Manure & $126.50 \mathrm{a}$ & $137.00 \mathrm{a}$ & $2.36 \mathrm{a}$ & $2.95 \mathrm{a}$ & $1.29 \mathrm{a}$ & $1.38 \mathrm{a}$ \\
LSD(0.05) & 36.07 & 29.36 & 0.97 & 0.8 & 0.47 & 0.49 \\
SE & 11.71 & 9.53 & 0.31 & 0.26 & 0.15 & 0.16 \\
ICP7992 & $125.56 \mathrm{a}$ & $124.89 \mathrm{a}$ & $2.53 \mathrm{a}$ & $2.77 \mathrm{a}$ & $1.35 \mathrm{a}$ & $1.30 \mathrm{a}$ \\
ICP7343 & $115.67 \mathrm{a}$ & $119.78 \mathrm{a}$ & $2.79 \mathrm{a}$ & $3.12 \mathrm{a}$ & $1.25 \mathrm{a}$ & $1.55 \mathrm{a}$ \\
LSD(0.05) & 29.45 & 23.97 & 0.79 & 0.66 & 0.38 & 0.4 \\
SE & 9.56 & 7.78 & 0.26 & 0.21 & 0.12 & 0.13 \\
\hline
\end{tabular}

Means with the same alphabet down the groups are not significantly different from each other at $5 \%$ level of significance, SE: Standard error, LSD: Least significance differences.

Table 6: Effect of soil amendment type on the soil status of Ogbagu Ogume farmland at harvest.

\begin{tabular}{|c|c|c|c|c|c|c|c|c|c|c|}
\hline \multirow[t]{2}{*}{ Soil amendment } & \multirow[t]{2}{*}{$\mathrm{pH}$} & O. C & \multirow[t]{2}{*}{$\mathrm{N}$} & \multirow{2}{*}{$\begin{array}{c}\mathrm{P} \\
\mathrm{Mg} / \mathrm{kg}\end{array}$} & $\mathrm{Ca}^{2+}$ & $\mathrm{Mg}^{2+}$ & $\mathrm{Na}^{+}$ & $\mathrm{K}^{+}$ & \multirow{2}{*}{ TEB } & \multirow{2}{*}{ TEA } \\
\hline & & $\mathrm{g} / \mathrm{kg}$ & & & \multicolumn{4}{|c|}{ 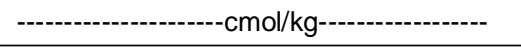 } & & \\
\hline Pre A & $6.01 b$ & $13.2 \mathrm{c}$ & $0.8 d$ & $9.8 \mathrm{c}$ & $1.68 b$ & $0.70 \mathrm{~b}$ & $0.13 c$ & $0.09 c$ & $1.55 d$ & $0.50 \mathrm{~b}$ \\
\hline Post A & $5.75 c$ & $12.8 \mathrm{~d}$ & $1.8 \mathrm{c}$ & $9.11 d$ & $1.64 b$ & $0.55 c$ & $0.19 a$ & $0.06 \mathrm{~d}$ & $2.61 \mathrm{a}$ & $0.54 \mathrm{ab}$ \\
\hline Post B & $6.02 b$ & $13.4 \mathrm{~b}$ & $2.2 \mathrm{~b}$ & $13.7 \mathrm{~b}$ & $1.70 \mathrm{a}$ & $0.70 \mathrm{~b}$ & $0.17 \mathrm{~b}$ & $0.52 \mathrm{a}$ & $1.92 b$ & $0.61 a$ \\
\hline Post C & $6.20 \mathrm{a}$ & $14.1 \mathrm{a}$ & $2.4 a$ & $14.4 a$ & $1.84 a$ & $0.89 a$ & $0.20 \mathrm{a}$ & $0.34 b$ & $1.88 \mathrm{c}$ & $0.54 a b$ \\
\hline $\operatorname{LSD}(0.05)$ & 0.09 & 0.16 & 0.19 & 0.19 & 0.10 & 0.09 & 0.01 & 0.02 & 0.02 & 0.10 \\
\hline SE & 0.03 & 0.05 & 0.06 & 0.06 & 0.03 & 0.03 & 0.004 & 0.01 & 0.01 & 0.03 \\
\hline
\end{tabular}

Means with the same alphabet down the groups are not significantly different from each other at $5 \%$ level of significance, SE: Standard error, LSD: Least significance differences. A, B and C represents fallow soil, NPK 15:15:15 and Poultry manure amended soil respectively, TEB: Total exchangeable bases and TEA: Total exchangeable acidity.

sample. The highest sodium content $(0.20 \pm 0.004)$ was observed in the poultry manure amendment which was not significantly different from the fallowed soil $(0.19 \pm 0.004)$. The potassium content $(0.52 \pm 0.01)$ of the NPK 15:15:15 amendment was significantly higher than the rest treatments. It also had the highest total exchangeable acidity $(0.61 \pm 0.03)$ but it was only significantly higher than the pre soil sample status. However, the total exchangeable bases was highest in the fallowed soil $(2.61 \pm 0.01)$ and it was significantly higher than the rest amendments and pre soil status.
Although the $\mathrm{pH}$ varied among the soil amendments and pre soil status, the range is within the optimal conditions for the cultivation of pigeon pea (Shiferaw and Zerihun, 2019). The soil physico-chemical properties supported the improved soil status as the nitrogen contents of the soil improved being that pigeon pea is a legume that helps in fixing atmospheric nitrogen to the soil and thus followed the phosphorus content of the soil. Dhaka et al. (2019) had earlier reported increase in the nitrogenous content and plant uptake from soil amended with nitrogenous based synthetic 
fertilizer. This also supported the earlier finding of Bansh and Psychas (1992). However, the soil organic content dropped in the post soil analysis of the fallowed soil because of the cultivation activity in the soil due to plants intake. However, it increased in the poultry manure amended soil because of the organic debris constituting the poultry manure that was applied. Also, it was only the fallowed soil that the potassium content reduced at the post analysis level and this can be attributed to the addition of external potassium embedded in the NPK and poultry manure, while the potassium constituent in the initial fallowed soil is been depleted by the crops grown in it which depleted the value. The increased level of potassium in the NPK 15:15:15 and poultry manure amended soils is as a result of its ion been released from the inorganic fertilizer for the plants uptake, a stance earlier reported by Deo and Khandelwal (2009).

\section{CONCLUSION}

In Nigeria, pigeon pea production has been successfully incorporated as a staple by the local farmers in the Southern Guinea Savana agro-ecological zone where Ogume is located. This study subjected two early maturing varieties of pigeon pea to different soil amendment in Ndokwa community, Delta State, Nigeria. The research of this revealed the potential of the crop without amendment and the soil type supports the growth and yield of pigeon pea. Hence, the farmers do not need to spend extra finance in treating the soil for pigeon pea cultivation in Ndokwa community, Delta State.

\section{REFERENCES}

Balpande, S., Sarap, P. and Ghodpage, R. (2016). Effect of potassium and sulphur on nutrient uptake, yield and quality of pigeon pea (Cajanus cajan). Agricultural Science Digest. 36(4): 323-325.

Bansh, T.R. and Psychas, J.P. (1992). The AFNETA Alley Farming Training Manual. Vol. 1. Alley Farming Network for Tropical Africa, Ibadan, Nigeria.

Dhaka, A., Kumar, S., Singh, K., Kumar, A. and Kamboj, N. (2019). Nitrogen use efficiency, economic return and yield performance of pigeonpea [Cajanus cajan (L.) Millsp.] as influenced by nipping and fertility levels. Legume Research- An International Journal. 43(1): 105-110.

Deo, C. and Khadelwal, R.B. (2009). Effect of P and S nutrition on yield and quality of chickpea. J. Indian Soc. Soil Sci. 57: 352-356.

Egbe, O.M. and Adeyemo, M.O. (2006). Estimation of the effect of intercropped pigeon pea on the yield and yield components of maize in Southern Guinea Savanna of Nigeria. Journal of Sustainable Development in Agriculture and Environment. 2: $107-1$.

Emefiene, M.E., Joshua, V.I., Nwadike, C., Yaroson, A.Y. and Zwalnan, N.D.E. (2014). Profitability analysis of pigeon pea (Cajanus Cajan) production in Riyom Lga of Plateau State. Academic Journal of Interdisciplinary Studies. 3(7): 44. doi:10.5901/ajis.2014.v3n7p44.
FAOSTAT: FAO Statistic Division. (2015). Retrieved from http:// faostat.fao.org/faostat/collections?version= extandhasbulk Oandsubset=agriculture. Last Accessed 06 Jan 2015.

Folu, M., Dania, O. and Bamidele, J.F. (2007). Potential of pigeon pea (Cajanus cajan) for planted fallow in Edo State, Nigeria. Asian Journal of Plant Sciences. 6(3): 490-495.

Jat, R.A. and Ahlawat, I.P.S. (2010). Effect of organic manure and sulphur fertilization in pigeon pea and groundnut intercropping system. Indian J. Agronomy. 55: 276-282

Kumawat, N., Rajendra, P.S., Kumar, R. and Hari, O.M. (2013). Effect of integrated nutrient management on the performance of sole and intercropped pigeonpea (Cajanus cajan) under rainfed conditions. Indian Journal of Agronomy. 58(3): 309-315.

Mallesha, K., Muralli, M.K., Shruthi, G.K. and Basavaraj, P. (2014). Effect of foliar application of water soluble fertilizer on protein yield, dry matter production and grain yield of pigeonpea. J. Green Farming 5:117-119.

Piper, C.S. (1966). Soil and Plant Analysis. Hans Publishers Bombay PP 368.

Ojwang, D., Nyankanga, R., Imungi, J., Olanya, M. and Ukuku, D. (2016). Cultivar preference and sensory evaluation of vegetable pigeon pea (Cajanus cajan) in Eastern Kenya. Food Security. 8(4): 757-767. doi:10.1007/s12571-0160592-8

Ojwang, D., Nyankanga, R., Japheth, I. and Olanya, M. (2016). Plant characteristics and growth parameters of vegetable pigeon pea cultivars. Hort Technology. 26. 97-105. 10.21273/HORTTECH.26.1.97.

Okoko, O., Obaga, S. and Okeyo, B. (2002). Introduction of Improved Pigeon Pea Genotypes in the Marginal Areas of Lake Victoria Region of South West Kenya. In: Partici-patory Technology Development for Soil Management by Small Holders in Kenya. [J.G. Mureithi, G.K.K. Gachene, F.N. Muyekho, M. Onyango, L. Mose and O. Magenya (eds.)]. Kenya Agr. Res. Inst., Nairobi, Kenya. p. 299-301.

Shiferaw, T. and Zerihun, A. (2019). Effect of soil incorporation pruned pigeon pea and nitrogen on system productivity in maize/pigeon pea intercropping. Ethiopian Journal of Agricultural Science. 29(1): 73-83.

Tabo, R., Ezueh, M.I, Ajayi, O., Asiegbu, J.E. and Singh, L. (1995). Pigeon pea production and utilization in Nigeria. International Chickpea Pigeon pea Newsletter. 2: 47-49

Tian, G., Salako, F.K., Ishida, F. and Zhang, J. (2001). Biological Restoration of Degraded Alfisol in the Humid Tropics Using Planted Woody Fallow: Synthesis of 8-years Results. In: Sustaining the Global Farm [Stott, D.E., R.A. Mohtar and G.C. Steinhardt (Eds)], Selected papers from the $10^{\text {th }}$ International Soil Conservation Organization Meeting, May 24-29, 1999, Purdue University and the USDA-ARS National Soil Erosion Research Laboratory, pp: 333-337.

Ureigho, U.N., Ezekiel, Z., Ohwo, O.A. and Okunomo, K. (2020). Evaluation of shifting cultivation practices by farmers in Ndokwa West Local Government Area of Delta State, Nigeria. Nigerian Journal of Agriculture, Food and Environment. 16(1): 132-143. 